\title{
Erratum to: Suprasubduction Volcanism of Chukotka Terrane in the Late Jurassic-Early Cretaceous (Arctic Region, Russia)
}

\author{
E. V. Vatrushkina ${ }^{a,}$ *, M. I. Tuchkova ${ }^{a}$, and S. D. Sokolov ${ }^{a}$ \\ ${ }^{a}$ Geological Institute, Russian Academy of Sciences, Moscow, 119017 Russia \\ *e-mail: evat_095@mail.ru \\ Submitted February 11, 2019; accepted for publication February 11, 2019
}

DOI: $10.1134 / \mathrm{S} 0016852120110011$

The title of the article should read as follows:

Suprasubduction Volcanism of Chukotka Terrane in the Late Jurassic-Early Cretaceous (Arctic Region, Russia)

The original article can be found online at

https://doi.org/10.1134/S0016852119060128 